\title{
Efficacy of emamectin benzoate in the control of Argulus coregoni (Crustacea: Branchiura) on rainbow trout Oncorhynchus mykiss
}

\author{
T. Hakalahti ${ }^{1, *}$, Y. Lankinen ${ }^{2}$, E. T. Valtonen ${ }^{1}$ \\ ${ }^{1}$ Department of Biological and Environmental Science, University of Jyväskylä, PO Box 35 (ya), 40014 Jyväskylä, Finland \\ ${ }^{2}$ Savon Taimen Oy, 77700 Rautalampi, Finland
}

\begin{abstract}
Efficacy of in-feed treatment with emamectin benzoate (Slice) for the control of ectoparasitic Argulus coregoni on rainbow trout Oncorhynchus mykiss was tested under laboratory and field conditions. In both experiments fish were fed with fish feed to deliver a therapeutic dose of 0 (control) or $50 \mu \mathrm{g}$ emamectin benzoate $\mathrm{kg}^{-1} \mathrm{~d}^{-1}$ (treatment) for a period of $7 \mathrm{~d}$. After $3 \mathrm{~d}$ of challenge with $A$. coregoni in the laboratory, the infestation level in treated fish was lower than that observed in the controls $(\mathrm{p}<0.001)$. Efficacy of $100 \%$ against newly hatched $A$. coregoni metanauplii and adults and $80 \%$ against juveniles was observed. In the field, trial medication was undertaken at 2 sections on a flow-through canal with 1 wk between treatments. Mean infestations of 100 to 200 A. coregoni per fish with $100 \%$ prevalence was recorded prior to medication. Following the treatment, the mean infestation of $A$. coregoni on fish declined to 31 lice per fish at Section A and 2.5 lice per fish at Section B. Then, after $28 \mathrm{~d}$ of treatment, the number of lice per fish was $<1$ at Section $\mathrm{A}_{\text {; }}$ in contrast the mean number of $A$. coregoni per fish at the control section was $>20$. The prevalence of $A$. coregoni remained $<50 \%$ over a period of $72 \mathrm{~d}$ of treatment, but started to increase again thereafter. This suggests that emamectin benzoate concentration in fish remained at a level high enough to kill A. coregoni over a period of 9 wk. Emamectin benzoate was very effective in the control of $A$. coregoni infesting trout.
\end{abstract}

KEY WORDS: Emamectin benzoate $\cdot$ Slice $\cdot$ Argulus coregoni $\cdot$ Ectoparasite $\cdot$ Control

\section{INTRODUCTION}

Ectoparasitic fish lice in the genus Argulus can create a very serious threat to both farmed and wild fish populations. The seasonal variation of temperature in northern latitudes influences the population dynamics of lice. Highest infestation levels of A. foliaceus (L.) and A. coregoni (Thorell) are recorded during the warmest months between May and August (Pasternak et al. 2000, Hakalahti \& Valtonen 2003). A. coregoni over-winters only as eggs in Finland, and the eggs are usually deposited on hard substrates such as stones (Hakalahti et al. 2004b). The hatching of lice eggs starts with a high peak in the spring, when the water temperature exceeds $10^{\circ} \mathrm{C}$ (Mikheev et al. 2001, Hakalahti \& Valtonen 2003). However, the recruitment of $A$. coregoni metanauplii (Hakalahti \& Valtonen 2003) and the hatching pattern, even within cohorts of eggs laid by individual females, is asynchronous and has been shown to extend over several months (Hakalahti et al. 2004a). The attached fish lice pierce the skin of the host by their modified mouthparts and feed on blood while simultaneously releasing toxic anticoagulants into the fish (Stammer 1959, LaMarre \& Cochran 1992). Secondary bacterial and fungal infections invade the louse feeding site as the fish lice grow and may weaken the fish further, sometimes leading to mortality (Lester \& Roubal 1995).

Severe infestations by Argulus species have been reported throughout the world (Shimura 1983, Menezes et al. 1990, Gault et al. 2002, Hakalahti \& Valtonen 2003) and control attempts traditionally have been based upon bath immersion treatments using a variety of chemical compounds (e.g. Kabata 1970, 
Mohan et al. 1986, Singhal et al. 1986, Jafri \& Ahmed 1994). Most of the treatments have proven ineffective to some extent, stressful to fish and the environment, and usually require several treatments to eradicate the parasites. Stress faced by the fish during the treatment may impair their immune status, thus rendering them more susceptible to diseases, e.g. metazoan community structure on fish reflects the state of the water ecosystem (Valtonen et al. 1997). The development of treatments administered in feed would avoid the stress associated with bath immersion treatments and could be useful in the control of ectoparasites.

Emamectin benzoate (4"-deoxy-4" epimethylaminoavermectin $B_{1}$ ) is the active ingredient in the in-feed aquaculture parasiticide, Slice (Schering-Plough Animal Health). The efficacy of emamectin benzoate (50 $\mu \mathrm{g} \mathrm{kg}^{-1}$ for $7 \mathrm{~d}$ ) has been demonstrated against the parasitic copepods Lepeophtheirus salmonis and Caligus elongatus on Atlantic salmon Salmo salar (Stone et al. 1999, 2000a,b,c, Treasurer et al. 2002), and Salmincola edwardsii on brook trout, Salvelinus fontinalis (Duston \& Cusak 2002). Stone et al. (2000a) ascertained that the duration of efficacy against $L$. salmonis on salmon was up to $10 \mathrm{wk}$. The mode of action of avermectins is to increase the permeability of chloride ions in the neurons of invertebrate inhibitory synapses, which results in the paralysis and death of ectoparasites infesting fish (Arena et al. 1995, Vassilatis et al. 1997).

The trials reported here evaluated the efficacy of emamectin benzoate for control of Argulus coregoni infesting rainbow trout, Oncorhynchus mykiss (Walbaum) under controlled laboratory and field conditions. Fish in the field trial were continuously exposed to re-infestation by $A$. coregoni adults and juveniles dispersed from untreated sections of the farm and by metanauplii hatched over several weeks from overwintered eggs, since the hatching pattern of A. coregoni eggs is asynchronous (see Mikheev et al. 2001, Hakalahti \& Valtonen 2003). Willis \& Ling (2003) found that the susceptibility of planktonic marine copepods varies depending on the developmental stage, i.e. nauplii and copepodite $\mathrm{EC}_{50}$-values were significantly lower than those for the adults. Therefore, in the laboratory experiment sensitivity among 3 life-stages (metanauplius, juvenile, adult) of A. coregoni to emamectin benzoate was compared.

\section{MATERIALS AND METHODS}

Medicated feed. Medicated feed, Slice (Schering Plough Animal Health), was prepared (BioMar AS) by coating the feed pellets with emamectin benzoate and oil, incorporated at a rate of $10 \mathrm{mg}$ emamectin benzoate $\mathrm{kg}^{-1}$ of feed. The basal ration in the field trial fed to the rainbow trout $2+\mathrm{yr}$ of age was $7.0 \mathrm{~mm}$ feed pellets and was $5.0 \mathrm{~mm}$ feed in a laboratory trial fed to fish of $1+$ yr of age.

Laboratory experiment. The efficacy of emamectin benzoate in prevention and control of Argulus coregoni infestations was tested under laboratory conditions at a commercial fish farm in central Finland in 2002. The experimental challenge of emamectin benzoate-medicated fish with lice was repeated 3 times using 3 ontogenetic stages of $A$. coregoni. The developmental stages of lice used in the experiment were: 24 to $36 \mathrm{~h}$ old metanauplii (mean length $0.7 \mathrm{~mm}, \mathrm{SD} \pm 0.02$ ), juveniles $(3.9 \mathrm{~mm}, \mathrm{SD} \pm 0.11)$ and adults $(11.8 \mathrm{~mm}, \mathrm{SD} \pm$ 2.12). A. coregoni metanauplii were obtained from egg clutches collected from the earth ponds of the fish farm and stored in water at temperatures below $9^{\circ} \mathrm{C}$, to prevent hatching before the experiment started (Hakalahti $\&$ Valtonen 2003). At the start of the experiment, hatching of the lice eggs was induced by exposing them to sunlight in the front of the window at room temperature (see Mikheev et al. 2001). Adult parasites were collected from infested rainbow trout Oncorhynchus mykiss (total length 30 to $40 \mathrm{~cm}$ ), and juvenile A. coregoni were collected from the flow-through tank (volume $500 \mathrm{l}$ ) containing small rainbow trout (80 to $100 \mathrm{~g}$ weight), which was established to let A. coregoni metanauplii grow to the juvenile stage. Prior to experiments, all lice were pre-starved for a day to stimulate high foraging motivation (see Mikheev et al. 2000).

Prior to the experiment, 100 uninfected rainbow trout (weight range 111 to $263 \mathrm{~g}$ ) were captured and 50 were randomly allocated into each of 2 established flow-through tanks (volume $500 \mathrm{l}$ ). After $24 \mathrm{~h}$ of acclimation, fish in the experimental tank were fed with medicated feed for 7 consecutive days, with a nominal dose of $50 \mu \mathrm{g}$ emamectin benzoate $\mathrm{kg}^{-1} \mathrm{~d}^{-1}$. Fish in the control tank were fed an unmedicated feed at rate of $0.5 \%$ biomass $\mathrm{d}^{-1}$. New fish were used in each experiment. The water temperature during the medication period was ambient, average daily temperature being $21^{\circ} \mathrm{C}\left(\mathrm{SD} \pm 1.3^{\circ} \mathrm{C}\right)$ during the metanauplius and adult trial and $23^{\circ} \mathrm{C}\left(\mathrm{SD} \pm 0.5^{\circ} \mathrm{C}\right)$ during the juvenile trial. Due to the structure of the maintaining tanks, we were not able to collect and estimate the amount of uneaten feed during the medications.

The day following each medication period, both medicated and control fish were randomly allocated into smaller tanks in $45 \mathrm{l}$ of water, without the flow-through system. Each of the 5 replicate tanks contained 5 fish. In these tanks water circulation was provided by using air pumps and air stones, and water was changed every day. After a $12 \mathrm{~h}$ acclimation of fish, Argulus coregoni were released to all tanks, and, following $3 \mathrm{~d}$ challenge period, fish were anesthetized individually, lice were removed, and the efficacy of the medicine was calcu- 
lated. The numbers of louse individuals introduced into each experimental tank (5 fish) were either 200 metanauplii, 50 juveniles, or 20 adults, and the efficacy of the medicine was calculated as: \%efficacy $=1-$ (mean number of lice in control/mean number of lice in treatment) $\times 100$. After the experiment, fish were released back to their rearing site. In total 3 fish died during exposures to A. coregoni.

Field trial. The field trial was carried out at a commercial fish farm in central Finland during the summer 2002. The farm consists of earthen ponds containing Atlantic salmon Salmo salar, whitefish Coregonus lavaretus, brown trout $S$. trutta, and rainbow trout Oncorhynchus mykiss of various age groups. Water flows to the ponds through canals from the nearby lake. The farm also includes a large flow-through canal containing rainbow trout $2+$ yr of age. This farming canal, which has a bottom of mud and stones, is about $1 \mathrm{~km}$ in length, $8 \mathrm{~m}$ wide, and $2 \mathrm{~m}$ deep. Bridges and grating divide the canal into 9 interconnected sections (Fig. 1). Section A, where the sampling of this study was started, was the only section containing very heterogeneous fish stock (total length 28.8 to $49.5 \mathrm{~cm}$ ), transferred from the ponds. The daily water temperatures in the canal in 2002 are represented in Fig. 2.

Samples of Argulus coregoni were collected from rainbow trout in 3 separate sections (A, B, and $C$ ) of the farming canal that contained infested fish (Fig. 1).

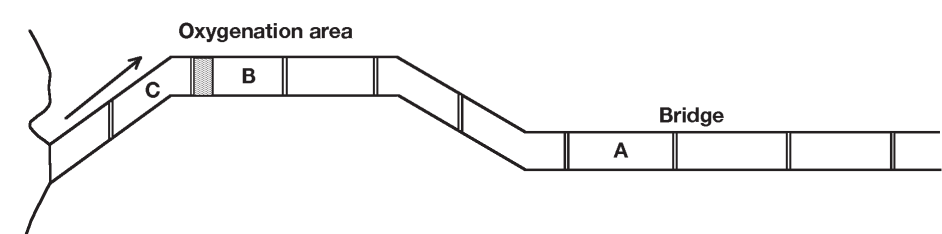

Fig. 1. Schematic diagram of the farming canal at a commercial fish farm in central Finland. Argulus coregoni samples were collected from the canal sections $A, B$, and $C$. The arrow indicates the direction of water flow. Fish in Section $\mathrm{C}$ were untreated, and fish in Sections A and B were treated with emamectin benzoate for A. coregoni infestations

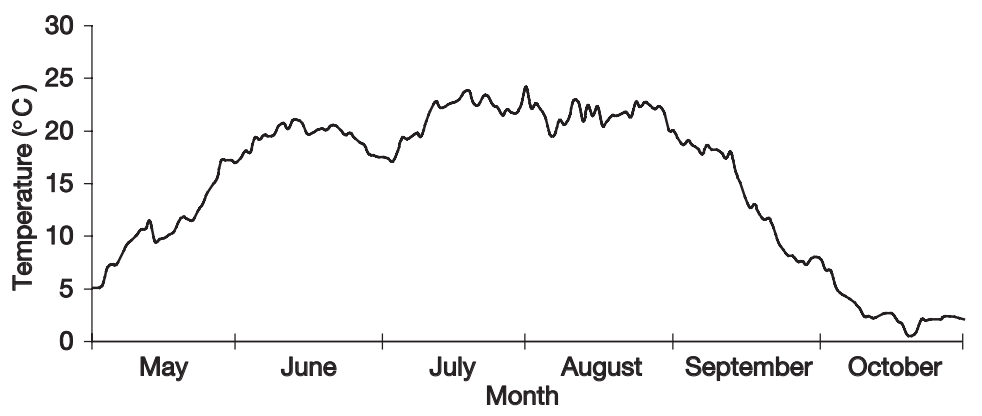

Fig. 2. Daily water temperatures at the fish farm during the openwater period 2002
Section A contained a stock of about 10000 fish, Section B contained about 6000 fish and Section C contained about 20000 fish. Weekly samples were taken from Section A between 14 May and 13 September 2002 (Table 1). Fish in Section A were treated with emamectin benzoate-medicated feed for 7 consecutive days (27 May to 2 June 2002) at a dose of $50 \mu \mathrm{g} \mathrm{kg}^{-1} \mathrm{~d}^{-1}$. The medicated feed was spread over the whole section area by using a tractor-mounted feed spreader, to facilitate uniform feeding rate among the fish. Samples were taken weekly from Section B between 31 May and 1 July, after which the fish were harvested for food consumption and no further samples were available. This section was treated with emamectin benzoate from 3 to 9 June using the same procedure as in Section A. In both sections individual lice collections were taken from 15 fish before treatment and from either 15, 20, or 50 fish after treatment at every sampling time (see Table 1). All sections of the canal, except the Section C located upstream from Sections A and B (see Fig. 1), were treated with emamectin benzoate. Due to fish management practices, collection of weekly samples from Section C was possible only between 9 and 31 July. Samples obtained from Section C, together with data from an earlier study on population structure and the seasonal cycle of $A$. coregoni undertaken in 1999 and 2001 (Hakalahti \& Valtonen 2003), served as a control for the medicated Sections A and B in late summer.

For sampling, the fish were first gathered with a seine net and were then captured individually with a dip net. Fish were anesthetized in a white container with MS-222. Fish skin, gills, and mouth cavities were inspected for argulids. Detached and removed lice were counted and preserved in $70 \%$ alcohol for later species identification and measurement in the laboratory. After recovering from narcosis, fish were released back to the same site. The distribution of parasites among individual fish was depicted using the terms prevalence and abundance according to Bush et al. (1997) and calculating the variance to mean ratio $\left(s^{2} / \bar{x}\right)$ of the numbers of Argulus coregoni per fish.

\section{RESULTS}

\section{Laboratory experiment}

Variability within treatments was not found in the mean number of lice per tank of 5 fish in either adult or juvenile Argulus coregoni groups (Kruskal-Wallis test: $\mathrm{p}>0.05)$. Therefore, data from all tanks within a treatment in the adult and juvenile lice groups were pooled. Three days following the fish lice challenge, the mean number of established 
adult (Mann-Whitney test: $U=87.5, \mathrm{p}<0.001$ ) and juvenile A. coregoni was significantly lower in the medicated group than in their control $(U=78.0, \mathrm{p}<0.001)$, and efficacy of $100 \%$ and $80 \%$ was recorded, respectively (Table 2 ). After the experiment, only 2 motile adult lice were found in the water, but 5 fish were found infected with $12,5,2$, 2, or 1 juvenile A. coregoni, respectively.

Emamectin benzoate-medicated fish challenged with newly hatched Argulus coregoni metanauplii were $100 \%$ devoid of lice $(U=0.0, \mathrm{p}<0.001)$, showing high efficacy. Variability between the control tanks infected with $A$. coregoni metanauplii was found (Kruskal-Wallis test: $\chi^{2}=16.5, \mathrm{p}=0.002$ ). Three days post-challenge each tank contained 9 $(\mathrm{SD} \pm 2.7), 12(\mathrm{SD} \pm 2.6), 23(\mathrm{SD} \pm 6.8), 26(\mathrm{SD} \pm 11.3)$, and $13(\mathrm{SD} \pm 2.2)$ established lice per fish. Emamectin benzoate medication was very efficient and lethal to A. coregoni.

\section{Field trial}

Severe Argulus coregoni infestations were recorded in May 2002 at the fish farm. Three weekly samples were taken before the emamectin benzoate treatment in Section A of the flow-through canal. At that time the weekly prevalence was $100 \%$, and the mean abundance of $A$. coregoni on fish was $140(\mathrm{SD} \pm 274.8)$ (Table 1). There were no differences in mean numbers of lice on fish in Sections A and B collected before treatment (Mann-Whitney test: $U=218.0, \mathrm{p}=0.369$; Table 1). In samples taken from Section A 4 and $7 \mathrm{~d}$ after treatment, the numbers of lice on fish had decreased to $65(\mathrm{SD} \pm 83.2, U=78.5, \mathrm{p}=0.158)$ and 31 ( $\mathrm{SD} \pm 54.3, U=53.0, \mathrm{p}=0.001$ ) lice per fish, respectively (Figs. 3 \& 4). At the same time (31 May to 3 June), the abundance of lice in Section B, which is connected to Section A and was not treated yet, was

Table 1. Argulus coregoni on Oncorhynchus mykiss. Number of fish examined (n), mean number of lice at each sampling time at each sampling site (A, B, and C), and the minimum and maximum numbers of lice on fish are given. Dashed lines indicate the beginning of emamectin benzoate treatment of $7 \mathrm{~d}$

\begin{tabular}{|c|c|c|c|c|c|c|c|c|c|c|c|c|}
\hline \multirow{2}{*}{$\begin{array}{l}\text { Date } \\
\text { (d/mo) }\end{array}$} & \multirow[b]{2}{*}{$\mathrm{n}$} & \multicolumn{3}{|c|}{ Section A } & \multicolumn{5}{|c|}{ Section B } & \multicolumn{3}{|c|}{ Section C } \\
\hline & & Mean $( \pm \mathrm{SD})$ & Min. & Max. & $\mathrm{n}$ & Mean $( \pm \mathrm{SD})$ & Min. & Max. & $\mathrm{n}$ & Mean $( \pm \mathrm{SD})$ & Min. & Max. \\
\hline $14 / 05$ & 15 & $164( \pm 321.6)$ & 15 & 1315 & & & & & & & & \\
\hline $21 / 05$ & 15 & $155( \pm 346.1)$ & 4 & 1390 & & & & & & & & \\
\hline $27 / 05$ & 15 & $103( \pm 108.5)$ & 10 & 349 & & & & & & & & \\
\hline$\overline{3} \overline{1} / 05$ & $\overline{1} \overline{5}$ & $65( \pm 83.2)$ & 3 & $2 \overline{8} 3$ & 15 & $191( \pm 105.5)$ & 8 & 862 & & & & \\
\hline 03/06 & 20 & $31( \pm 54.3)$ & 0 & 175 & 15 & $112( \pm 148.3)$ & 16 & 589 & & & & \\
\hline 06/06 & 20 & $7( \pm 18.3)$ & 0 & 82 & 20 & $7( \pm 9.8)$ & 1 & $\overline{3} \overline{5}$ & & & & \\
\hline $11 / 06$ & 50 & $7( \pm 19.5)$ & 0 & 114 & 50 & $2.5( \pm 16.1)$ & 0 & 114 & & & & \\
\hline $18 / 06$ & 50 & $9( \pm 30.8)$ & 0 & 202 & 50 & $14( \pm 88.2)$ & 0 & 624 & & & & \\
\hline $24 / 06$ & 50 & $4( \pm 16.1)$ & 0 & 113 & 50 & $1( \pm 3.2)$ & 0 & 22 & & & & \\
\hline $01 / 07$ & 50 & $0.4( \pm 1.18)$ & 0 & 8 & 50 & $3( \pm 2.6$ & 0 & 11 & & & & \\
\hline 09/07 & 50 & $0.9( \pm 2.71)$ & 0 & 13 & & & & & 20 & $24( \pm 12.2)$ & 5 & 53 \\
\hline $18 / 07$ & 50 & $0.3( \pm 0.85)$ & 0 & 5 & & & & & 20 & $23( \pm 16.7)$ & 3 & 70 \\
\hline $24 / 07$ & 50 & $0.3( \pm 0.71)$ & 0 & 3 & & & & & 50 & $10( \pm 9.9)$ & 0 & 54 \\
\hline $31 / 07$ & 50 & $0.4( \pm 0.66)$ & 0 & 2 & & & & & 50 & $2( \pm 1.7)$ & 0 & 6 \\
\hline 08/08 & 50 & $1( \pm 1.8)$ & 0 & 8 & & & & & & & & \\
\hline $16 / 08$ & 50 & $2( \pm 2.2)$ & 0 & 12 & & & & & & & & \\
\hline $22 / 08$ & 50 & $2( \pm 2.2)$ & 0 & 9 & & & & & & & & \\
\hline $30 / 08$ & 50 & $3( \pm 3.8)$ & 0 & 21 & & & & & & & & \\
\hline 05/09 & 50 & $4( \pm 4.1)$ & 0 & 16 & & & & & & & & \\
\hline $13 / 09$ & 50 & $4( \pm 6.5)$ & 0 & 35 & & & & & & & & \\
\hline
\end{tabular}

Table 2. Laboratory experiment on the efficacy of in-feed treatment, emamectin benzoate, against 3 developmental stages of lice Argulus coregoni on rainbow trout Oncorhynchus mykiss. Fish received feed at a rate to deliver a nominal dose of either 0 (control) or $50 \mu \mathrm{g}$ emamectin benzoate $\mathrm{kg}^{-1} \mathrm{~d}^{-1}$ (medication) for $7 \mathrm{~d}$, after which they were challenged over $3 \mathrm{~d}$ with $A$. coregoni. Number of fish in each treatment was 25 ( 5 tanks each containing 5 fish). n: number of $A$. coregoni per fish

\begin{tabular}{|c|c|c|c|c|c|}
\hline \multirow{2}{*}{$\begin{array}{l}\text { Developmental } \\
\text { stage }\end{array}$} & \multicolumn{2}{|c|}{ Medication } & \multicolumn{2}{|c|}{ Control } & \multirow{2}{*}{$\begin{array}{c}\text { Efficacy } \\
(\%)\end{array}$} \\
\hline & Mean $( \pm \mathrm{SD})$ & Prevalence (\%) & Mean $( \pm \mathrm{SD})$ & Prevalence (\%) & \\
\hline Adult $(\mathrm{n}=4)$ & $0( \pm 0)$ & 0 & $2( \pm 2.1)$ & 71 & 100 \\
\hline Juvenile $(\mathrm{n}=10)$ & $1( \pm 2.6)$ & 24 & $5( \pm 4.1)$ & 100 & 80 \\
\hline Metanauplius $(\mathrm{n}=40)$ & $0( \pm 0)$ & 0 & $17( \pm 8.9)$ & 100 & 100 \\
\hline
\end{tabular}



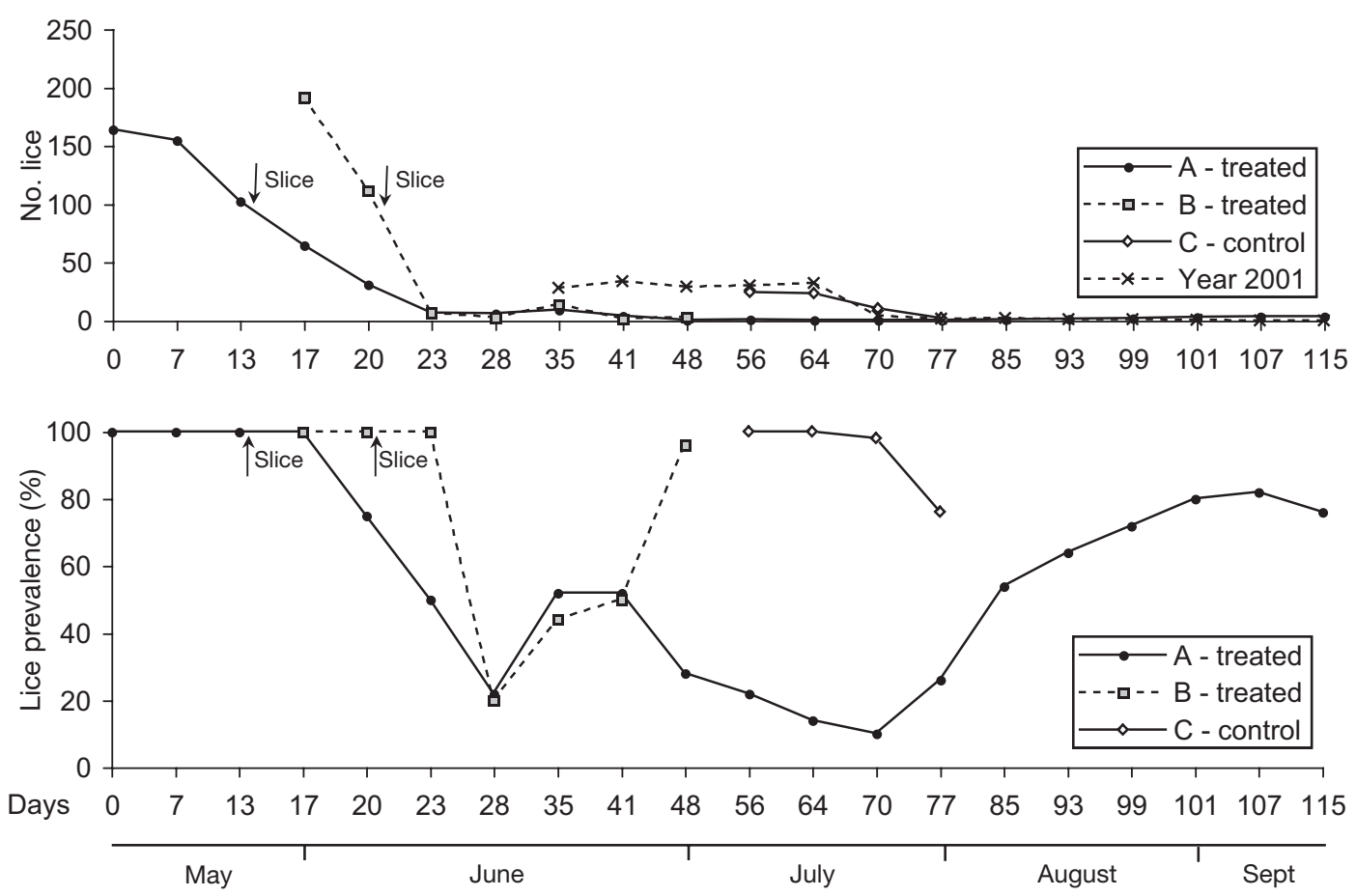

Fig. 3. Prevalence and mean number of Argulus coregoni infesting rainbow trout, Oncorhynchus mykiss. The field trial of emamectin benzoate was conducted on a commercial fish farm in central Finland in 2002. Average number (upper panel) and prevalence (lower panel) of lice on fish following treatment with $50 \mu \mathrm{g}$ emamectin benzoate $\mathrm{kg}^{-1} \mathrm{~d}^{-1}$ for 7 consecutive days. Treatments in Sections A and B are depicted with arrows. Argulus infestation data for 2001were obtained from Hakalahti \& Valtonen (2003)

Fig. 4. Field trial of emamectin benzoate against Argulus coregoni infesting rainbow trout Oncorhynchus mykiss, conducted on a commercial fish farm in central Finland in 2002. Frequency distributions of the numbers of lice on fish at 3 sampling sites of the flow-through canal. Section A was treated from 27 May to 2 June, and Section B was treated from 3 to 9 June with $50 \mu \mathrm{g}$ emamectin benzoate $\mathrm{kg}^{-1} \mathrm{~d}^{-1}$ for $7 \mathrm{~d}$. The number of fish examined and the variance to mean ratio of number of $A$. coregoni attached on each fish are indicated in the legends
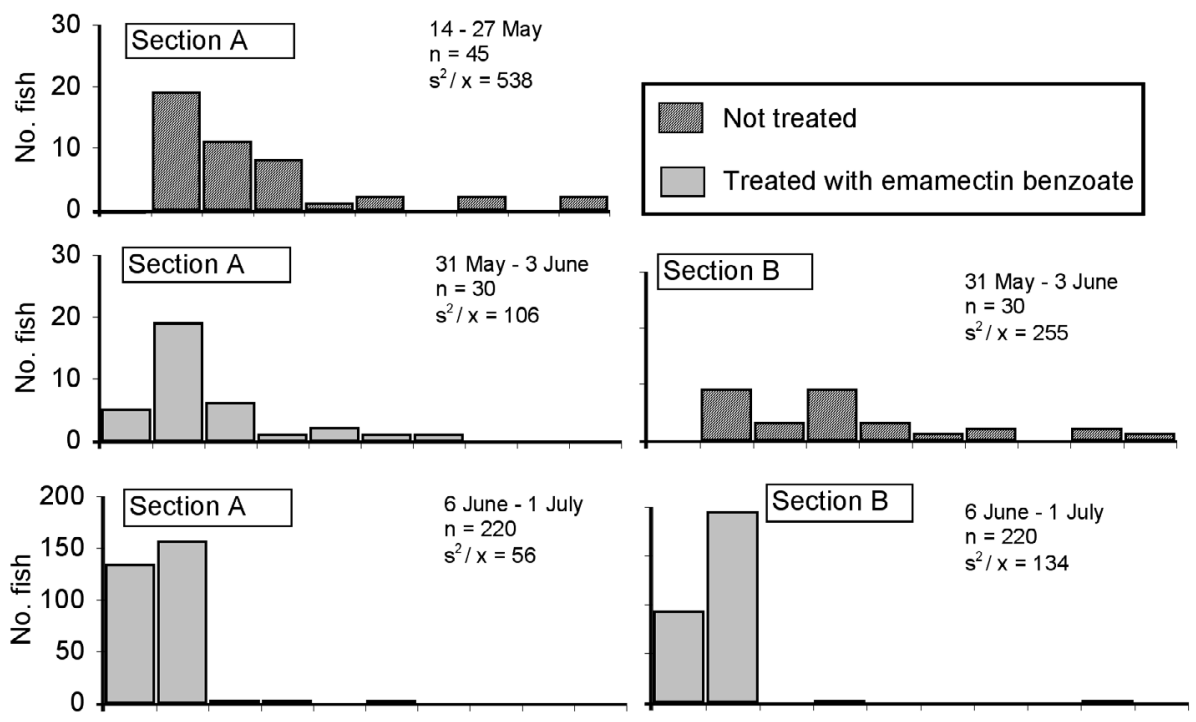

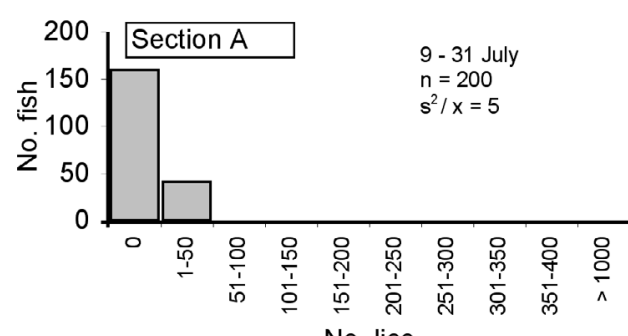

No. lice

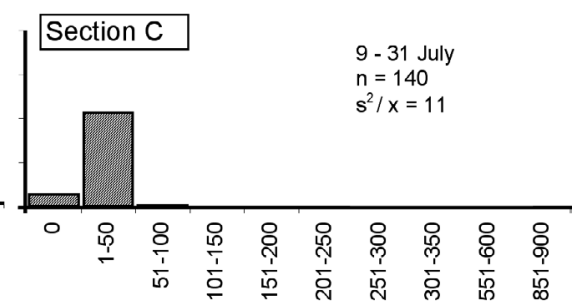

No. lice 
notably higher than in Section A, which was treated ( $U$ $=218.0, \mathrm{p}<0.001)$. The same decline in A. coregoni numbers was seen in Section B after treatment with emamectin benzoate from 3 June onwards. Within $3 \mathrm{~d}$ after treatment, the mean number of lice per fish had decreased from $151(\mathrm{SD} \pm 196.5)$ to 7 (SD \pm 9.8$)(U=$ 13.0, $\mathrm{p}<0.001)$.

The prevalence of Argulus coregoni on fish in Section A decreased during the $14 \mathrm{~d}$ period after medication ending on 11 June, increased slightly between 18 and 24 June, but decreased thereafter (Fig. 3). From 57 $\mathrm{d}$ after treatment, the prevalence of lice gradually increased. However, $>1$ mo post-treatment (between 9 and 31 July), the abundance of lice in Section A was significantly lower than in the control Section C sampled simultaneously $(U=2389.0, \mathrm{p}<0.001)$. At that time, an average of $0.5(\mathrm{SD} \pm 1.51)$ and $11(\mathrm{SD} \pm 13.1)$ lice per fish were collected from Sections A and C, respectively. Although the prevalence of lice increased towards autumn, the mean number of $A$. coregoni infesting fish in Section A remained $<5$ lice per fish up to 13 September, when the sampling ended (Table 1).

Before the medication, the variance to mean ratio $\left(s^{2} / \bar{x}\right)$ of the number of lice per fish in Section A was 538 , indicating very high aggregation of lice populations among individual fish (Fig. 4). The fish length in Section A was not correlated with the number of Argulus coregoni on fish (Pearson correlation coefficient: $r=$ $0.220, \mathrm{p}=0.151$ ). In samples collected 4 and $7 \mathrm{~d}$ after the $7 \mathrm{~d}$ medication period, the variance to mean ratio of lice had decreased to 106. At the same time the variance to mean ratio was 255 in Section B, which was still untreated.

\section{DISCUSSION}

The field and laboratory experiments presented here proved that emamectin benzoate is effective in the control of Argulus coregoni on rainbow trout, Oncorhynchus mykiss. A $100 \%$ efficacy was achieved against newly hatched $A$. coregoni metanauplii and adults in the laboratory experiment. Although most emamectin benzoate-medicated fish were devoid of juvenile A. coregoni as well, a slightly lower total efficacy of $80 \%$ was recorded for them. This may imply differences in susceptibility between the life-stages of A. coregoni, as has been observed in some plankton copepods (e.g. Medina et al. 2002, Willis \& Ling 2003). Observed differences in lice mortality could also be due to differences in feed intake between the individual fish during medication. The temperature during the juvenile trial was higher, about $23^{\circ} \mathrm{C}$, compared to the water temperature of $21^{\circ} \mathrm{C}$ during the adult and metanauplius trial. High temperature coupled with handling stress may have reduced feed intake by certain fish individuals in the laboratory; thus, the actual medication doses were not able to be determined. During the field trial, medications were performed in early summer, when the water temperature increased from 15.4 to $20.4^{\circ} \mathrm{C}$. Results, which will be discussed later, showed that fish with the highest parasite burdens at the fish farm lost their juvenile $A$. coregoni due to medication.

The seasonal pattern of Argulus coregoni population dynamics after application of emamectin benzoate in 2002 was markedly different from that reported in our previous study undertaken in 1999 and 2001 (Hakalahti \& Valtonen 2003). In both studies, the first $A$. coregoni metanauplii hatched from over-wintered eggs were observed on fish when water temperature exceeded $10^{\circ} \mathrm{C}$. Infestation levels of 100 to $200 \mathrm{~A}$. coregoni per fish were recorded in weekly samples taken before medication (14 May to 3 June), whereas, in all samples collected in 2001,<40 lice per fish were found (see Hakalahti \& Valtonen 2003). Argulus were not controlled extensively in 2001, which explains the much higher infection level observed in 2002. The over-wintering A. coregoni eggs laid in 2001 accumulated on the bottom of the canal and started to hatch the following spring. A. coregoni females lay approximately 317 eggs (Hakalahti et al. 2004a). Following the emamectin benzoate treatment in 2002, the numbers of A. coregoni in the medicated Section A of the canal declined, but remained at the same level in sections of the canal (Section B) that had not been treated yet. A more rapid decrease in $A$. coregoni numbers followed medication undertaken a week later in Section $B$, when the water temperature was higher. Temperature can affect the onset of maximum efficacy of emamectin benzoate, e.g. maximum efficacy against Lepeophtheirus salmonis in Atlantic salmon Salmo salar was achieved more rapidly at temperatures of 13.0 to $15.5^{\circ} \mathrm{C}$ than at temperatures of 7.2 to $8.5^{\circ} \mathrm{C}$ (Stone et al. 2000c). In the present study an average of 31 lice per fish were recorded in Section A and 2.5 lice per fish in Section B at the end of the emamectin benzoate medication period of $7 \mathrm{~d}$, when the water temperatures in Sections A and B were 18.0 and $20.4^{\circ} \mathrm{C}$, respectively. However, the resulting efficacy was the same in both sections: within $3 \mathrm{~d}$ after treatment the number of lice per fish in Section A had decreased to 7.

Although the seasonal dynamics of Argulus coregoni populations are temperature dependent and variability between years occurs (Hakalahti \& Valtonen 2003), they cannot explain the sharp decrease in lice numbers following the treatment. At the end of the medication period in Section A (3 June), the largest recorded A. coregoni were only $3 \mathrm{~mm}$ in length. Females of $A$. coregoni start to lay eggs upon reaching about $8 \mathrm{~mm}$ in 
length (Hakalahti et al. 2004a). In 2001 females started to lay eggs from early July onwards, and the egg laying period extended over 3.5 mo (Hakalahti \& Valtonen 2003, Hakalahti et al. 2004b). In the present study, $<1$ A. coregoni per fish was found in July, and the numbers remained low up to the end of September. That low abundance was recorded only at the end of August in 2001, when most females had finished their egg laying and were dying (Hakalahti \& Valtonen 2003). The notable decrease in A. coregoni numbers observed in late July in untreated fish (Section C) of the present study is in accordance with the earlier study on the population dynamics.

The numbers of Argulus coregoni per fish showed an aggregated distribution, the variance to mean ratio $\left(s^{2} / \bar{X}\right)$ being 538 and 255 in 2 sampling sections of the canal, before the emamectin benzoate medication. The variance to mean ratio was tremendously decreased after treatment, suggesting that fish with high parasite loads had either died or recovered from Argulus sp. infestation. No adverse mortality due to lice infestation was observed among treated fish following medication, suggesting that the fish received an effective dose of emamectin benzoate. It must be pointed out that treatments were performed in early summer, soon after the majority of the A. coregoni population of that year had recruited on fish and lice were still small in size (Mikheev et al. 2001, Hakalahti \& Valtonen 2003). Growing Argulus spp. juveniles may expose fish to fungal and bacterial infections by irritating the skin that can affect the fish's feeding and can sometimes lead to death of the host (Lester \& Roubal 1995).

In a field trial, where fish were continuously exposed to Argulus coregoni recruited from untreated sections of the canal or hatched from eggs on the canal bottom (Hakalahti et al. 2004b), the duration of efficacy of emamectin benzoate extended well beyond the medication period. Although the prevalence of $A$. coregoni increased from $20 \%$ to $>50 \% 21$ to $28 \mathrm{~d}$ following medication, the decreasing trend in the prevalence of lice thereafter suggests that $A$. coregoni were not able to survive on medicated fish. About $9 \mathrm{wk}$ from the start of the application of emamectin benzoate, the prevalence of lice on fish started to increase steadily, suggesting that the efficacy of the medicine was ceasing. Due to its extended duration of efficacy, emamectin benzoate has been used as a preventative treatment for salmon smolts before the transfer to sea (Stone et al. 2002), when high-order efficacy against sea lice Lepeophtheirus salmonis, was still achieved $10 \mathrm{wk}$ after treatment (Stone et al. 2000a).

In conclusion, emamectin benzoate was very efficient for the control of Argulus coregoni on rainbow trout. By medicating the fish, which initially had high
A. coregoni infestations, we were able to prevent fish mortality and break the reproductive cycle of the parasite. Due to the strategy of $A$. coregoni to overwinter only as eggs, the mean lice infestation levels on fish would have decreased towards the end of the open-water period without control (Mikheev et al. 2001, Hakalahti \& Valtonen 2003). In that case, presumably, the majority of fish would have been killed by Argulus and the lice egg stock on the bottom of the canal would have increased heavily. Eggs of $A$. coregoni can remain viable buried in sediments for at least $2 \mathrm{yr}$, and retain the ability to hatch throughout an extended period (Mikheev et al. 2001). At this particular fish farm, a single emamectin benzoate treatment administered in-feed in early summer proved to be an effective control strategy, due to extended residence of the medicine in fish tissues. However, to overcome such A. coregoni mass infestation as in the present case, application of the medication should be administered over several years and preferably in all ponds of the farm simultaneously. The medication should be given in early May, prior to the spring peak of $A$. coregoni metanauplii hatching. Present results suggest a need for another treatment after $9 \mathrm{wk}$. However, the duration of efficacy of emamectin benzoate in the control of lice should be studied experimentally.

Acknowledgements. We thank H. Häkkinen and M. Bandilla for assistance during the experiments. We also thank R. Endris for editorial assistance and for helpful comments. The study was funded by the Graduate School for Biological Interactions, the Foundation for Research of Natural Resources in Finland, SUNARE-project of the Academy of Finland, Savon Taimen Oy and Schering-Plough Animal Health.

\section{LITERATURE CITED}

Arena JP, Liu KK, Paress PS, Frazier EG, Cully DF, Mrozik H, Schaeffer JM (1995) The mechanism of action of avermectins in Caenorhabditis elegans, correlation between activation of glutamate-sensitive chloride current membrane binding and biological activity. J Parasitol 81: 286-294

Bush AO, Lafferty KD, Lotz JM, Shostak AW (1997) Parasitology meets ecology on its own terms. Margolis et al. revisited. Parasitology 83:575-583

Duston J, Cusack RR (2002) Emamectin benzoate: an effective in-feed treatment against the gill parasite Salmincola edwardsii on brook trout. Aquaculture 207:1-9

Gault NFS, Kilpatric DJ, Steward MT (2002) Biological control of the fish louse in a rainbow trout fishery. J Fish Biol 60: $226-237$

Hakalahti T, Valtonen ET (2003) Population structure and recruitment of the ectoparasite Argulus coregoni Thorell (Crustacea: Branchiura) on a fish farm. Parasitology 127: 79-85

Hakalahti T, Häkkinen H, Valtonen ET (2004a) Ectoparasitic Argulus coregoni (Crustacea: Branchiura) hedge their bets - studies on egg hatching dynamics. Oikos (in press) 
Hakalahti T, Pasternak AF, Valtonen ET (2004b) Seasonal dynamics of egg laying and egg-laying strategy of the ectoparasite Argulus coregoni (Crustacea: Branchiura). Parasitology 128:655-660

Jafri SIH, Ahmed SS (1994) Some observations on mortality in major carps due to fish lice and their chemical control. Pak J Zool 26:274-276

Kabata Z (1970) Diseases of fishes. Book I. Crustacea as enemies of fishes. THF Publications, Neptune City, NJ

LaMarre E, Cochran PA (1992) Lack of host species selection by the exotic parasitic crustacean, Argulus japonicus. J Freshw Ecol 7:77-80

Lester RJG, Roubal FR (1995) Phylum Arthropoda. In: Woo PTK (ed) Fish diseases and disorders, Vol 1. Protozoan and metazoan infection. Cab International, Wallingford

Medina M, Barata C, Telfer T, Baird DJ (2002) Age- and sexrelated variation in sensitivity to the pyrethroid cypermethrin in the marine copepod Acartia tonsa Dana. Arch Environ Contam Toxicol 42:17-22

Menezes J, Ramos MA, Pereira TG, Moreira Da Silva A (1990) Rainbow trout culture failure in a small lake as a result of massive parasitosis related to careless fish introductions. Aquaculture 89:123-126

Mikheev VN, Mikheev AV, Pasternak AF, Valtonen ET (2000) Light-mediated host searching strategies in a fish ectoparasite, Argulus foliaceus L. (Crustacea: Branchiura): the role of vision and selectivity. Parasitology 120:409-416

Mikheev VN, Pasternak AF, Valtonen ET, Lankinen Y (2001) Spatial distribution and hatching of overwintered eggs in a fish ectoparasite Argulus coregoni Thorell (Crustacea: Branchiura). Dis Aq Org 46:123-128

Mohan CV, Ramaiah N, Shanbhogue SL (1986) Effects of some therapeutics on fish ectoparasites. Environ Ecol 4: 98-100

Pasternak AF, Mikheev VN, Valtonen ET (2000) Life history characteristics of Argulus foliaceus L (Crustacea: Branchiura) populations in central Finland. Ann Zool Fenn 37: $25-35$

Shimura S (1983) Seasonal occurrence, sex ratio and site preference of Argulus coregoni Thorell (Crustacea: Branchiura) parasitic on cultured freshwater salmonids in Japan. Parasitology 86:537-552

Singhal RN, Jeet S, Davies RW (1986) Chemotherapy of 6 ectoparasitic diseases of cultured fish. Aquaculture 54: 165-171

Editorial responsibility: Wolfgang Körting,

Hannover, Germany
Stammer HJ (1959) Beiträge zur Morphologie, Biologie und Bekämpfung der Karpfenläuse. Z Parasitenkd 19:135-208

Stone J, Sutherland IH, Sommerville C, Richards RH, Varma KJ (1999) The efficacy of emamectin benzoate as an oral treatment of sea lice, Lepeophtheirus salmonis (Krøyer), infestations in Atlantic salmon, Salmo salar L. J Fish Dis 22:261-270

Stone J, Sutherland IH, Sommerville C, Richards RH, Endris RG (2000a) The duration of efficacy following oral treatment with emamectin benzoate against infestations of sea lice, Lepeophtheirus salmonis (Krøyer), in Atlantic salmon Salmo salar L. J Fish Dis 23:185-192

Stone J, Sutherland IH, Sommerville C, Richards RH, Varma KJ (2000b) Commercial trials using emamectin benzoate to control sea lice Lepeophtheirus salmonis in Atlantic salmon Salmo salar. Dis Aquat Org 41:141-149

Stone J, Sutherland IH, Sommerville C, Richards RH, Varma KJ (2000c) Field trials to evaluate the efficacy of emamectin benzoate as an oral treatment of sea lice, Lepeophtheirus salmonis (Krøyer) and Caligus elongatus Nordman, infestations in Atlantic salmon, Salmo salar. Aquaculture 186:205-219

Stone J, Roy WJ, Sutherland IH, Ferguson HW, Sommerville C, Endris R (2002) Safety and efficacy of emamectin benzoate administered in-feed to Atlantic salmon, Salmo salar L., smolts in freshwater, as a preventative treatment against infestations of sea lice, Lepeophtheirus salmonis (Krøyer). Aquaculture 210:21-34

Treasurer JW, Wallace C, Dear G (2002) Control of sea lice on farmed Atlantic salmon $S$. salar L. with the oral treatment emamectin benzoate (SLICE). Bull Eur Assoc Fish Pathol $22: 375-380$

Valtonen ET, Holmes JC, Koskivaara M (1997) Eutrophication, pollution and fragmentation: effects on parasite communities in roach (Rutilus rutilus) and perch (Perca fluviatilis) in 4 lakes in central Finland. Can J Fish Aquat Sci 54:572-585

Vassilatis DK, Elliston KO, Paress PS, Hamelin, M, Arena JP, Schaeffer JM, van der Ploeg LH, Cully DF (1997) Evolutionary relationship of the ligand-gated ion channels and the avermectin sensitive, glutamate-gated chloride channels. J Mol Evol 44:501-508

Willis KJ, Ling N (2003) The toxicity of emamectin benzoate, an aquaculture pesticide, to planktonic marine copepods. Aquaculture 221:289-297

Submitted: March 3, 2004; Accepted: May 10, 2004 Proofs received from author(s): August 12, 2004 